\title{
Isolasi Bakteri Endofit Asal Padi Gogo dan Potensinya sebagai Agens Biokontrol dan Pemacu Pertumbuhan
}

\author{
Isolation of Endophytic Bacteria from Upland Rice and \\ Its Role as Biocontrol Agents and Plant Growth Inducer
}

\author{
Abdul Munif ${ }^{1 *}$, Suryo Wiyono ${ }^{1}$, Suwarno ${ }^{2}$ \\ ${ }^{1}$ Institut Pertanian Bogor, Bogor 16680 \\ ${ }^{2}$ Balai Besar Penelitian Tanaman Padi, Subang 41256
}

\begin{abstract}
ABSTRAK
Bakteri endofit banyak mendapat perhatian karena potensinya dalam memacu pertumbuhan dan kemampuannya dalam meningkatkan ketahanan tanaman terhadap penyakit dan hama tanaman. Penelitian ini bertujuan mengisolasi bakteri endofit beberapa varietas padi gogo dari berbagai daerah di Indonesia dan menguji potensinya sebagai agens hayati untuk pengendalian penyakit dan pertumbuhan tanaman. Isolasi bakteri endofit dilakukan dengan metode sterilisasi permukaan dengan alkohol dan natrium hipoklorit pada medium trypsic soy agar (TSA). Lebih dari 200 isolat bakteri endofit berhasil diisolasi dan dikoleksi dari beberapa varietas tanaman padi gogo. Isolat tersebut diseleksi untuk melihat kemampuan antibiosisnya terhadap cendawan patogen secara in vitro dan memacu pertumbuhan tanaman. Hasil seleksi menunjukkan 41 isolat bakteri endofit menunjukkan reaksi antibiosis terhadap Rhizoctonia solani dan 25 isolat bakteri endofit terhadap Pyricularia grisea pada medium potato dextrose agar (PDA) serta 8 isolat bakteri endofit menunjukkan aktivitas antibiosis terhadap $R$. solani maupun $P$. grisea pada medium PDA maupun TSA. Hasil uji pemacu pertumbuhan menunjukkan 12 isolat bakteri endofit dapat memacu pertumbuhan akar dan tajuk tanaman padi. Hal ini mengindikasikan bahwa beberapa bakteri endofit asal padi gogo berpotensi sebagai agens biokontrol dan pemacu pertumbuhan tanaman.
\end{abstract}

Kata kunci: bakteri endofit, padi gogo, Pyricularia grisea, Rhizoctonia solani

\begin{abstract}
Studies on endophytic bacteria has been increasing recently due to its potency to promote plant growth and induce plant tolerance to pests and diseases. The research was undergone to isolate endophytic bacteria from different varieties of upland rice from various growing regions in Indonesia, followed by evaluation of their biocontrol and plant growth activities. Isolation of endophytic bacteria was based-on surface-sterilized method using alcohol and $\mathrm{NaOCl}$ on trypsic soy agar (TSA) media. More than 200 isolates was successfully isolated and the selected isolates were subjected to in vitro assay for their ability to produce antibiotic and promote plant growth. The result showed 41 isolates of endophytic bacteria had antibiosis activity to Rhizoctonia solani, 25 isolates to Pyricularia grisea on potato dextrose agar (PDA) medium and 8 isolates showed antibiosis activity to both $R$. solani and $P$. grisea on both PDA and TSA. The result of plant growth test, showed 12 isolates of endophytic bacteria induced the growth of root and shoot of rice plant. This indicated that some of the endophytic bacteria have the potency as biocontrol agents and inducer of plant growth.
\end{abstract}

Key words: endophytic bacteria, Pyricularia grisea, Rhizoctonia solani, upland rice

\footnotetext{
*Alamat penulis korespondensi: Departemen Proteksi Tanaman, Fakultas Pertanian, Institut Pertanian Bogor, Kampus Darmaga, Jalan Kamper, Bogor 16680

Tel: 0251-8629364, Faks: 0251-8629362, Surel: abdulmunif@ipb.ac.id
} 


\section{PENDAHULUAN}

Kehilangan hasil pertanian di Indonesia yang diakibatkan oleh gangguan hama dan penyakit masih sangat tinggi dan cenderung meningkat. Penggunaan pestisida untuk tujuan pengendalian hama dan penyakit tanaman masih merupakan cara yang paling disukai oleh petani. Penggunaan pestisida yang terlalu intensif dapat menyebabkan terjadinya residu pada bahan makanan, kontaminasi racun pestisida pada lingkungan, serta munculnya hama dan patogen yang resisten terhadap suatu pestisida. Pengendalian hayati yang difokuskan pada pemanfaatan komponen biologi, seperti mikroba antagonis merupakan salah satu pilihan teknologi pengendalian yang tepat dan perlu dikembangkan, karena akibat negatif terhadap lingkungan relatif kecil dan lebih berkelanjutan.

Bakteri endofit merupakan bakteri saprofit yang hidup dan berasosiasi dengan jaringan tanaman tanpa menimbulkan suatu gejala penyakit pada tanaman tersebut. Dilaporkan bahwa keberadaan bakteri-bakteri endofit di dalam jaringan tanaman selain berperanan dalam perbaikan pertumbuhan tanaman (plant growth promotion), juga karena kemampuannya menghasilkan zat pemacu tumbuh, memfiksasi nitrogen, memobilisasi fosfat, dan juga berperanan dalam kesehatan tanaman (plant health promotion). Bakteri endofit diduga mampu meningkatkan sistem pertahanan tanaman terhadap gangguan penyakit tanaman karena kemampuannya untuk memproduksi senyawa antimikrob, enzim, asam salisilat, etilena dan senyawa sekunder lainnya yang berperanan menginduksi ketahanan tanaman (Backman dan Sikora 2008).

Penelitian ini bertujuan mendapatkan isolat bakteri endofit dari beberapa varietas padi gogo yang berasal dari berbagai wilayah sentra padi gogo di Indonesia, menguji kemampuan aktivitas antibiosis isolat bakteri endofit yang diperoleh terhadap cendawan patogen Rhizoctonia solani dan Pyricularia grisea dan kemampuannya dalam memacu pertumbuhan tanaman padi.

\section{BAHAN DAN METODE}

\section{Isolasi Bakteri Endofit}

Sumber bakteri endofit diisolasi dari akar padi gogo yang dikumpulkan dari beberapa sentra produksi padi gogo di wilayah Jawa dan Sumatera. Tanaman padi gogo yang dipilih sebagai sampel ialah yang sehat dan menunjukkan pertumbuhan lebih baik dibandingkan dengan tanaman padi gogo lainnya dalam suatu populasi.

Isolasi bakteri endofit dilakukan mengikuti metode sterilisasi permukaan (Hallmann et al. 1997). Akar padi gogo dari lapangan dicuci bersih, dipotong dengan ukuran 1-2 cm. Potongan akar direndam dalam alkohol 70\% selama 1 menit dan dalam $\mathrm{NaOC1} 2.5 \%$ selama 2 menit selanjutnya dibilas 3 kali dengan air steril. Keberhasilan sterilisasi diuji dengan mengoleskan potongan akar pada medium trypsic soy agar (TSA) 10\% dan diinkubasi selama 2 hari. Akar yang benar-benar steril yang tidak terdapat bakteri yang tumbuh pada medium TSA tersebut digunakan sebagai bahan isolasi.

Sebanyak $1 \mathrm{~g}$ akar dihancurkan sampai halus dalam mortar steril. Sebanyak $1 \mathrm{~mL}$ suspensi akar dicampur dengan $9 \mathrm{~mL}$ air steril dalam tabung gelas. Suspensi akar selanjutnya diencerkan secara seri dengan konsentrasi $10^{-2}, 10^{-3}$, dan $10^{-4}$. Sebanyak $0.1 \mathrm{~mL}$ dari masing-masing pengenceran disebar pada medium TSA $10 \%$ dan diinkubasi selama 48 jam. Total populasi bakteri dihitung dan jenis bakteri dimurnikan pada medium TSA 100\% untuk digunakan pada kegiatan selanjutnya.

\section{Uji Antibiosis secara in Vitro}

Uji antibiosis dilakukan dengan teknik kultur ganda terhadap $R$. solani (isolat berasal dari Laboratorium Cendawan, Departemen Proteksi Tanaman, IPB) dan P. grisea (isolat berasal dari Balai Besar Penelitian Tanaman Padi, Muara, Bogor) pada medium TSA dan potato dextrose agar (PDA). Sebanyak 200 isolat bakteri endofit dilakukan uji antibiosis. Bakteri endofit uji digoreskan pada dua sisi medium dengan jarak $1 \mathrm{~cm}$ dari tepi. Selanjutnya isolat $R$. solani atau $P$. grisea yang berumur 7 hari dengan diameter $0.6 \mathrm{~cm}$ 
diletakkan pada pusat medium (Gambar 1). Pengamatan dilakukan terhadap zona hambatan yang dihasilkan pada hari ke-7 dan zona hambat dihitung menggunakan rumus:

$$
\text { Zona hambat }=\frac{\mathrm{R} 2-\mathrm{R} 1}{\mathrm{R} 1} \times 100 \%
$$

dengan R1, Jarak jari-jari miselium hingga tepi bakteri dan R2, Jarak jari-jari miselium hingga tepi zona hambat.

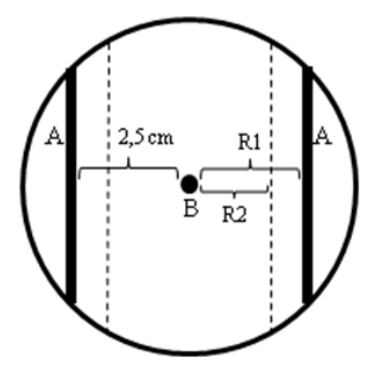

Gambar 1 Sketsa uji antibiosis bakteri endofit terhadap Rhizoctonia solani atau Pyricularia grisea. A, bakteri endofit uji; $\mathrm{B}$, isolat $R$. solani atau $P$. grisea.

\section{Uji Potensi Bakteri Endofit terhadap Pertumbuhan Padi}

Berdasarkan hasil uji antibiosis diambil 15 isolat endofit yang menunjukkan kemampuan antibiosis yang tinggi untuk diuji potensinya sebagai pemacu pertumbuhan benih padi gogo varietas Batutegi. Bakteri endofit uji ditumbuhkan pada medium TSA selama 2 hari. Selanjutnya koloni bakteri dipanen dan disuspensikan dengan menambahkan $10 \mathrm{~mL}$ akuades steril, diaduk, dan dimasukkan ke dalam tabung reaksi. Sebanyak 20 benih padi gogo direndam di dalam suspensi bakteri endofit dengan konsentrasi $10^{9}-10^{10} \mathrm{cfu} \mathrm{mL}^{-1}$ selama 6 jam. Selanjutnya benih ditanam pada medium kertas merang steril dalam cawan petri. Benih disimpan pada suhu ruangan dan setiap 2 hari disemprot dengan air steril secukupnya untuk menjaga kelembapan. Tanaman padi dipanen dan diukur panjang akar, tajuk, total tajuk, dan bobot kering tanaman pada hari ke-12 setelah tanam.

\section{Karakterisasi Bakteri Endofit}

Karakterisasi isolat bakteri dilakukan dengan pengamatan visual koloni, bentuk sel, uji pewarnaan Gram dan kemampuannya dalam menghasilkan fluoresens pada medium Kings'B dan sinar UV.

\section{HASIL}

\section{Isolasi Bakteri Endofit}

Lebih dari 200 isolat bakteri endofit berhasil diisolasi dari 12 varietas/galur tanaman padi gogo dari berbagai daerah di Jawa dan Sumatera. Populasi bakteri endofit yang diisolasi dari akar padi gogo berkisar antara $9.9 \times 10^{2} \mathrm{cfu}$ dan $6.2 \times 10^{6} \mathrm{cfu} \mathrm{g}^{-1}$ akar tanaman (Tabel 1).

\section{Kemampuan Antibiosis Bakteri Endofit}

Dari 200 isolat bakteri endofit yang dilakukan uji antibosis, sebanyak 41 isolat bakteri endofit menunjukkan reaksi antibiosis terhadap $R$. solani pada medium PDA dengan persentase zona hambat yang sangat beragam yang berkisar antara 3.4\% dan $70 \%$. Sebanyak 14 isolat bakteri menunjukkan reaksi antibiosis pada medium TSA dengan persentase zona hambat antara $14.5 \%$ dan $76.0 \%$ (Tabel 2). Hasil uji antibiosis terhadap $P$. grisea menunjukkan sebanyak 25 isolat bakteri endofit bereaksi menghambat pada medium PDA dengan zona hambat berkisar antara $13.0 \%$ dan $51.5 \%$ dan sebanyak 31 isolat menunjukkan zona hambatnya pada medium TSA berkisar antara 5.6\% dan 52.0\%. Terdapat 8 isolat bakteri endofit, yaitu isolat Aa72, Aa88, Aa89, Ci5, Ck1, Si15, Si42 dan Tw8 menunjukkan zona hambatnya terhadap $R$. solani maupun P. grisea pada medium PDA maupun TSA.

Kemampuan antibiosis setiap bakteri endofit untuk membentuk zona hambat sangat bervariasi. Hal ini dapat dilihat dalam uji in vitro isolat bakteri endofit terhadap cendawan $R$. solani dan $P$. grisea pada medium PDA dan TSA (Gambar 2). Reaksi antibiosis tertinggi terhadap $R$. solani ditunjukkan oleh isolat Aa89 dengan zona hambat $71 \%$ pada medium PDA dan isolat Tw8 dengan zona hambat sebesar $76.0 \%$ pada medium TSA, sedangkan reaksi antibiosis tertinggi terhadap $P$. grisea ditunjukkan oleh isolat Aa88 dengan zona 
Tabel 1 Total populasi bakteri endofit yang diisolasi dari akar padi gogo dari Jawa dan Sumatera

\begin{tabular}{llc}
\hline Asal daerah & Varietas & $\begin{array}{c}\text { Populasi bakteri endofit } \\
\left(\mathrm{cfu} \mathrm{g}^{-1} \text { akar }\right)\end{array}$ \\
\hline Banten & Padi gogo (lokal) & $1.3 \times 10^{3}-6.7 \times 10^{4}$ \\
Jawa Barat & Situpatenggang & $8.7 \times 10^{5}-4.7 \times 10^{6}$ \\
& Batutegi & $2.3 \times 10^{3}-1.9 \times 10^{6}$ \\
& Limboto & $2.9 \times 10^{4}-2.9 \times 10^{6}$ \\
& Wayroten & $2.0 \times 10^{3}-8.2 \times 10^{4}$ \\
& Tawi & $1.4 \times 10^{4}-6.2 \times 10^{6}$ \\
Jawa Tengah & Cikembar & $9.9 \times 10^{2}-2.2 \times 10^{3}$ \\
Lampung & Padi gogo (lokal) & $1.8 \times 10^{4}-2.3 \times 10^{6}$ \\
& Sirogol & $2.6 \times 10^{5}-5.6 \times 10^{6}$ \\
Riau & Tambun & $1.3 \times 10^{4}-3.4 \times 10^{6}$ \\
& Cantik & $1.3 \times 10^{4}-5.4 \times 10^{6}$ \\
& Padi gogo (lokal) & $*$ \\
\hline
\end{tabular}

*tidak diperoleh bakteri endofit karena sampel terkontaminasi

hambat $51.5 \%$ pada medium PDA dan isolat Ci9 dengan zona hambat $52.8 \%$ pada medium TSA.

\section{Kemampuan Bakteri Endofit Meningkatkan Pertumbuhan Tanaman Padi}

Dari 15 isolat bakteri endofit yang diuji diperoleh 12 isolat yaitu Aa90, Ci1, Ci8, Bt38, Bt28, Bt32, Li5, Li14, Ck33, Si30, Wr9, dan Si33 yang mampu memacu pertumbuhan akar tanaman padi dibanding kontrol, namun hanya isolat Si33 yang menunjukkan nilai yang berbeda nyata dengan kontrol pada taraf 5\% menurut uji Duncan. Pengaruh bakteri endofit terhadap panjang tajuk menunjukkan hampir semua isolat yang diuji kecuali isolat Bt38 mampu memacu pertumbuhan tajuk tanaman padi dibanding kontrol, namun hanya isolat $\mathrm{Si} 33$ yang berbeda nyata dibanding kontrol. Hasil pengukuran bobot kering tanaman padi perlakuan dengan bakteri endofit tidak menunjukkan perbedaan yang berarti dibandingkan dengan tanaman kontrol. Secara keseluruhan isolat Si33 merupakan isolat terbaik sebagai pemacu pertumbuhan tanaman padi dan menunjukkan perbedaan yang nyata untuk semua parameter dibandingkan dengan kontrol (Tabel 3 dan Gambar 3).

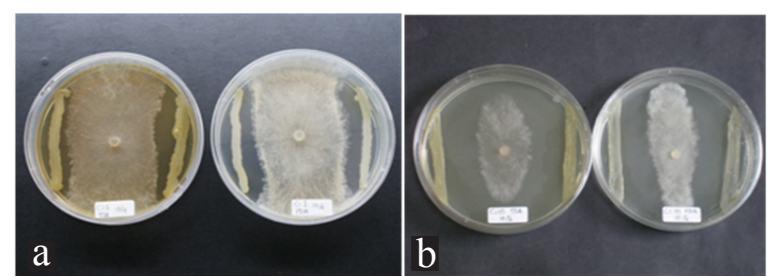

Gambar 2 Isolat bakteri endofit yang menunjukkan reaksi antibiosis: a, Rhizoctonia solani dan b, Pyricularia grisea.

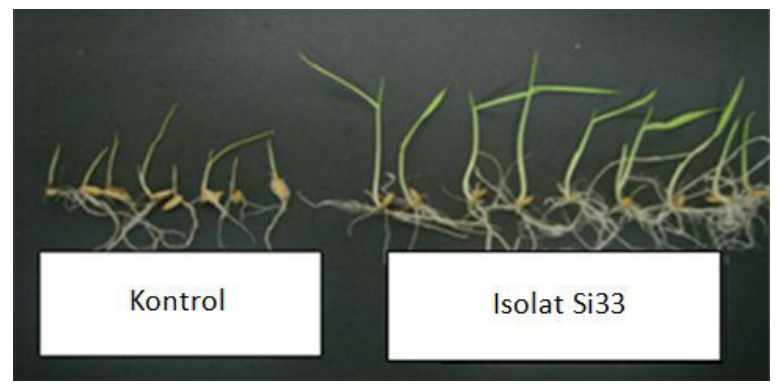

Gambar 3 Pengaruh perlakuan isolat bakteri endofit Si33 terhadap pertumbuhan padi gogo varietas Batutegi.

\section{Karakterisasi Isolat Bakteri Endofit}

Isolat bakteri endofit yang sudah terseleksi mampu menghambat cendawan patogen maupun memacu pertumbuhan tanaman padi selanjutnya dilakukan karakterisasi. Hasil karakterisasi terhadap 15 isolat yang potensial tersebut menunjukkan sebanyak 10 isolat tergolong ke dalam bakteri Gram positif dan 5 isolat termasuk Gram negatif (Tabel 4). 
Tabel 2 Uji antibiosis isolat bakteri endofit terhadap cendawan Rhizoctonia solani dan Pyricularia grisea

\begin{tabular}{|c|c|c|c|c|}
\hline \multirow[t]{2}{*}{ Kode isolat } & \multicolumn{2}{|c|}{$\begin{array}{c}\text { R. solani } \\
\text { Zona hambat }(\%)\end{array}$} & \multicolumn{2}{|c|}{$\begin{array}{c}\text { P. grisea } \\
\text { Zona hambat (\%) }\end{array}$} \\
\hline & Medium PDA & Medium TSA & Medium PDA & Medium TSA \\
\hline$\overline{\mathrm{Aa}} 71$ & 26.0 & 27.3 & 44.4 & 48.5 \\
\hline Aa72 & 19.1 & 29.1 & 48.5 & 50.0 \\
\hline $\mathrm{Aa} 88$ & 27.3 & 14.5 & 51.5 & 48.5 \\
\hline Aa89 & 71.0 & - & 43.3 & 44.1 \\
\hline Aa90 & 36.5 & - & 43.3 & 44.1 \\
\hline Aa91 & 40.7 & - & 42.5 & 14.6 \\
\hline AaJi & 27.2 & - & - & 26.8 \\
\hline Bt9 & 13.4 & - & 16.2 & 8.0 \\
\hline Bt15 & 26.3 & - & 5.4 & - \\
\hline $\mathrm{Bt} 28$ & 25.4 & - & - & - \\
\hline $\mathrm{Bt} 32$ & 47.0 & 31.0 & 51.3 & 8.0 \\
\hline $\mathrm{Bt} 38$ & 4.3 & 45.0 & 27.8 & 18.0 \\
\hline Ci1 & 27.6 & 29.7 & - & 27.8 \\
\hline $\mathrm{Ci6}$ & 51.9 & 48.2 & - & 43.1 \\
\hline $\mathrm{Ci} 8$ & 14.0 & 63.5 & - & 48.7 \\
\hline $\mathrm{Ci} 9$ & 49.1 & 14.6 & - & 52.8 \\
\hline Cilo & 63.2 & 23.4 & - & 49.8 \\
\hline Ci15 & 18.3 & - & 36.1 & 43.3 \\
\hline Ck1 & 12.4 & 23.1 & 13.3 & 21.1 \\
\hline Ck33 & 39.0 & - & 47.5 & 15.6 \\
\hline Ck34 & 46.6 & - & - & - \\
\hline GL12 & 23.5 & - & - & 37.1 \\
\hline Li11 & 36.4 & - & - & 37.1 \\
\hline Li15 & 7.8 & - & 23.2 & - \\
\hline $\mathrm{Si} 2$ & 11.4 & 18.0 & 24.3 & 30.6 \\
\hline Si14 & 3.4 & - & 15.8 & 16.2 \\
\hline Si15 & 18.3 & - & 38.9 & 5.6 \\
\hline Si16 & 26.5 & - & 16.7 & 14.2 \\
\hline $\mathrm{Si} 22$ & 38.9 & - & - & 19.4 \\
\hline $\mathrm{Si} 27$ & 54.8 & - & - & 10.5 \\
\hline Si33 & 10.3 & 29.3 & 42.1 & 36.8 \\
\hline Si34 & 57.1 & - & 28.9 & 12.8 \\
\hline $\mathrm{Si} 42$ & 7.8 & - & 21.6 & 13.1 \\
\hline Sp8 & 19.5 & - & - & - \\
\hline Sp19 & 28.7 & - & - & - \\
\hline $\mathrm{Sp} 24$ & 33.4 & - & - & - \\
\hline Sp27 & 33.6 & - & 13.4 & - \\
\hline Sp30 & 40.4 & 76.0 & 13.4 & - \\
\hline $\operatorname{Tm} 2$ & 24.3 & - & 10.3 & 22.0 \\
\hline Tw8 & 7.4 & & 41.0 & 16.4 \\
\hline Tw26 & 21.7 & & - & - \\
\hline
\end{tabular}

-, Isolat bakteri endofit tidak menunjukkan terbentuknya zona hambat 
Berdasarkan pengamatan pada medium King's B dengan bantuan sinar UV terdapat 2 isolat yaitu Bt28 dan Li14 menunjukkan kemampuannya dalam menghasilkan fluo- resens. Sedangkan dilihat dari bentuk selnya, 8 isolat dengan bentuk sel basil dan 7 isolat berbentuk kokus.

Tabel 3 Pengaruh perlakuan isolat bakteri endofit terhadap pertumbuhan akar, tajuk dan bobot padi gogo varietas Batutegi

\begin{tabular}{lcccc}
\hline $\begin{array}{l}\text { Kode } \\
\text { isolat }\end{array}$ & $\begin{array}{c}\text { Panjang tajuk } \\
(\mathrm{cm})\end{array}$ & $\begin{array}{c}\text { Panjang akar } \\
(\mathrm{cm})\end{array}$ & $\begin{array}{c}\text { Total panjang akar } \\
\text { dan tajuk } \\
(\mathrm{cm})\end{array}$ & $\begin{array}{c}\text { Bobot kering } \\
(\mathrm{g})\end{array}$ \\
\hline Kontrol & $4.96 \mathrm{c}-\mathrm{f}$ & $3.41 \mathrm{bc}$ & $8.38 \mathrm{~b}$ & $0.07 \mathrm{bc}$ \\
Li14 & $5.72 \mathrm{a}-\mathrm{f}$ & $3.82 \mathrm{abc}$ & $9.54 \mathrm{~b}$ & $0.07 \mathrm{bc}$ \\
Ci1 & $6.76 \mathrm{a}-\mathrm{d}$ & $4.58 \mathrm{abc}$ & $11.34 \mathrm{ab}$ & $0.07 \mathrm{bc}$ \\
Si2 & $3.73 \mathrm{f}$ & $5.03 \mathrm{abc}$ & $8.77 \mathrm{~b}$ & $0.06 \mathrm{bc}$ \\
Bt38 & $7.21 \mathrm{abc}$ & $2.54 \mathrm{c}$ & $9.76 \mathrm{~b}$ & $0.05 \mathrm{bc}$ \\
Sp24 & $4.25 \mathrm{ef}$ & $4.50 \mathrm{abc}$ & $8.75 \mathrm{~b}$ & $0.06 \mathrm{bc}$ \\
Si14 & $5.71 \mathrm{a}-\mathrm{f}$ & $5.06 \mathrm{abc}$ & $10.32 \mathrm{ab}$ & $0.07 \mathrm{bc}$ \\
Aa90 & $5.68 \mathrm{a}-\mathrm{f}$ & $3.80 \mathrm{abc}$ & $9.47 \mathrm{~b}$ & $0.05 \mathrm{bc}$ \\
Bt28 & $5.40 \mathrm{~b}-\mathrm{f}$ & $3.51 \mathrm{bc}$ & $8.91 \mathrm{~b}$ & $0.05 \mathrm{c}$ \\
Ci8 & $7.62 \mathrm{ab}$ & $4.26 \mathrm{abc}$ & $11.87 \mathrm{ab}$ & $0.07 \mathrm{bc}$ \\
Bt32 & $6.14 \mathrm{a}-\mathrm{f}$ & $5.58 \mathrm{ab}$ & $11.72 \mathrm{ab}$ & $0.07 \mathrm{bc}$ \\
Si30 & $6.56 \mathrm{a}-\mathrm{e}$ & $5.96 \mathrm{ab}$ & $12.54 \mathrm{ab}$ & $0.08 \mathrm{ab}$ \\
Wr9 & $5.93 \mathrm{a}-\mathrm{f}$ & $5.57 \mathrm{ab}$ & $11.50 \mathrm{ab}$ & $0.07 \mathrm{abc}$ \\
Li5 & $6.90 \mathrm{a}-\mathrm{d}$ & $4.16 \mathrm{abc}$ & $11.06 \mathrm{ab}$ & $0.06 \mathrm{bc}$ \\
Aa89 & $4.73 \mathrm{def}$ & $4.42 \mathrm{abc}$ & $9.15 \mathrm{ab}$ & $0.05 \mathrm{bc}$ \\
Si33 & $8.06 \mathrm{a}$ & $6.51 \mathrm{a}$ & $14.37 \mathrm{a}$ & $0.10 \mathrm{a}$ \\
\hline Ang & & &
\end{tabular}

Angka yang diikuti oleh huruf kecil yang sama pada kolom yang sama tidak berbeda nyata pada uji Duncan 5\%

Tabel 4 Karakter morfologi bakteri endofit yang potensial meningkatkan pertumbuhan dan kesehatan padi gogo

\begin{tabular}{llllccc}
\hline $\begin{array}{l}\text { Kode } \\
\text { isolat }\end{array}$ & Komoditas & Varietas & Asal daerah & $\begin{array}{c}\text { Pewarnaan } \\
\text { Gram } \\
(-/+)\end{array}$ & $\begin{array}{c}\text { Reaksi di } \\
\text { medum } \\
\text { King's B }\end{array}$ & $\begin{array}{c}\text { Bentuk sel } \\
\text { bakteri }\end{array}$ \\
\hline Aa89 & Alang-alang & Alang-alang & Jawa Barat & + & - & Basil \\
Aa90 & Alang-alang & Alang-alang & Jawa Barat & + & - & Basil \\
Bt28 & Padi gogo & Batutegi & Jawa Barat & - & + & Kokus \\
Bt32 & Padi gogo & Batutegi & Jawa Barat & + & - & Kokus \\
Bt38 & Padi gogo & Batutegi & Jawa Barat & + & - & Kokus \\
Ci1 & Padi gogo & Cikembar & Jawa Barat & + & - & Basil \\
Ci8 & Padi gogo & Cikembar & Jawa Barat & + & - & Basil \\
Li5 & Padi gogo & Limboto & Sumatera & - & - & Basil \\
Li14 & Padi gogo & Limboto & Sumatera & - & + & Basil \\
Si2 & Padi gogo & Sirogol & Sumatera & + & - & Kokus \\
Si14 & Padi gogo & Sirogol & Sumatera & + & - & Kokus \\
Si30 & Padi gogo & Sirogol & Sumatera & + & - & Kokus \\
Si33 & Padi gogo & Sirogol & Sumatera & + & - & Kokus \\
Sp24 & Padi gogo & Situpatenggang Jawa Barat & - & + & Basil \\
Wr9 & Padi gogo & Wayroten & Jawa Barat & - & + & Basil \\
\hline
\end{tabular}




\section{PEMBAHASAN}

Populasi bakteri endofit dari setiap varietas padi gogo maupun daerah asalnya cukup bervariasi. Populasi bakteri endofit, seperti halnya populasi bakteri rizosfer dipengaruhi oleh faktor biotik dan abiotik. Spesies bakteri endofit yang berasosiasi dengan tanaman bergantung pada genotipe tanaman, umur tanaman, jaringan yang diambil dan juga musim ketika isolasi dilakukan. Populasi bakteri endofit dipengaruhi oleh faktor lingkungan seperti, sifat tanah, bahan organik dalam tanah, teknik budi daya, pemupukan, dan aplikasi pestisida. Pemupukan N yang tinggi dapat menekan pertumbuhan endofit dibandingkan dengan pemupukan $\mathrm{N}$ yang rendah. Hal ini diduga karena kandungan $\mathrm{N}$ yang tinggi mengubah fisiologi tanaman sehingga mengurangi kandungan sukrosa tanaman yang dibutuhkan oleh bakteri endofit sebagai sumber karbon (Seghers et al. 2004). Kandungan bahan organik juga mempengaruhi dinamika bakteri endofit dalam tanaman (Hallmann et al. 1997; West et al. 2010). Bakteri endofit di dalam satu tanaman inang tidak terbatas pada satu spesies bakteri saja, namun terdiri atas beberapa genus dan spesies (Sturz et al. 1997). Tanaman memiliki relung yang beragam untuk bakteri endofit (Hallmann et al. 1997; Khan dan Doty 2009).

Beberapa bakteri endofit dilaporkan dapat berperan sebagai agens hayati yang berasosiasi dengan tanaman inangnya (Yang et al. 2011). Dalam penelitian ini beberapa isolat bakteri menunjukkan reaksi antibiosis terhadap $R$. solani dan $P$. grisea. Hasil penelitian sebelumnya juga melaporkan beberapa bakteri endofit dapat menekan serangan $R$. solani pada kapas (Pleban et al. 1995) dan pada kentang (Sturz 1995). Bakteri endofit sebagai agens hayati memiliki beberapa kelebihan dibandingkan dengan bakteri rizosfer karena keberadaannya lebih terlindungi dari stres faktor abiotik, menempati relung yang sama dengan umumnya patogen tanaman, kemampuannya dalam kolonisasi jaringan tananam dan proses translokasi senyawa metabolit ke dalam jaringan tanaman lebih baik (Hallmann et al. 1997).

Dalam penelitian ini diperoleh isolat bakteri endofit asal padi gogo yang menunjukkan kemampuannya meningkatkan pertumbuhan tanaman padi. Hasil penelitian lain juga melaporkan beberapa bakteri endofit dapat berasosiasi dan memacu pertumbuhan beberapa jenis tanaman, termasuk kentang (Sturz 1995), ketimun (Hallmann et al. 1997), tomat (Munif et al. 2000) dan cabai (Sundaramoorthy 2012). Mekanisme kerja bakteri endofit sebagai agens biokontrol dengan menghasilkan senyawa antimikroba untuk melawan patogen maupun dengan kemampuannya menghasilkan zat pengatur tumbuh maupun menfiksasi dan memobilisasi nitrogen dan fosfat yang berperanan dalam memacu dan memperkuat pertumbuhan ketahanan tanaman (Ikeda et al. 2010). Mekanisme antibiosis juga berkaitan erat dengan kemampuan isolat bakteri endofit menghasilkan enzim seperti kitinase, protease, dan selulase maupun senyawa sekunder lainnya yang sangat berperanan dalam menginduksi ketahanan tanaman (Hallmann et al. 1997). Enzim kitinase mampu mendegradasi kitin yang merupakan komponen dinding sel pada cendawan patogen $R$. solani, Fusarium oxysporum, dan Sclerotium rolfsii sedangkan enzim selulase mampu mengurai selulosa pada dinding sel cendawan Phytophthora capsici (Raaijmaker et al. 2008). Beberapa bakteri endofit juga dapat meningkatkan pertumbuhan tanaman karena dapat merangsang produktivitas hormon indole acetic acid, menghasilkan siderofor yang diperlukan dalam pertumbuhan tanaman. Khan dan Doty (2009) melaporkan bahwa bakteri endofit berpengaruh positif terhadap tanaman tomat meskipun ditumbuhkan di medium yang miskin hara. Dalam penelitian ini telah berhasil diperoleh beberapa isolat bakteri endofit yang berpotensi sebagai agens biokontrol dan pemacu pertumbuhan tanaman padi yang perlu diuji kefektifannya di rumah kaca dan lapangan. 


\section{UCAPAN TERIMA KASIH}

Penelitian ini memperoleh dana dari APBN Kementerian Riset dan Teknologi Tahun Anggaran 2011 dengan nomor kontrak: 1.01.04/SEK.IR/PPK/1/2011.

\section{DAFTAR PUSTAKA}

Backman PA, Sikora RA. 2008. Endophytes: an emerging tool for biological control. Biol Control. 46(1):1-3. doi:10.1016/j.bio control.2008.03.009.

Hallmann J, Quadt-Hallmann A, Mahaffee WF, Kloepper JW. 1997. Bacterial endophytes in agricultural crops. Can J Microbiol. 43(10):895-914. doi: 10.1139/ m97-131

Ikeda S, Okubo T, Anda M, Nakashita H, Yasuda M, Sato S, Kaneko T, Tabata S, Eda S, Momiyama A, Terasawa K, Mitsui H, Minamisawa K. 2010. Community- and genome-based views of plant-associated bacteria: plant-bacterial interactions in soybean and rice. Plant Cell Physiol. 51(9):1398-1410. doi:10.1093/pcp/pcq119.

Khan Z, Doty SL. 2009. Characterization of bacterial endophytes of sweet potato plants. Plant Soil. 322 (1-2):197-207. doi:10.1007/ s11104-009-9908-1.

Munif A, Hallmann J, Sikora RA. 2000. Evaluation of the biocontrol activity of endophytic bacteria from tomato against Meloidogyne incognita. Med Fac Landbouww Univ Gent. 65(2b):471-480.

Pleban S, Ingel F, Chet I. 1995. Control of Rhizoctonia solani and Sclerotium rolfsii in the greenhouse using endophytic Bacillus spp. Eur J Plant Pathol. 101(6):665-672.

Raaijmaker JM, Paulitz TC, Steinberg C. Alabouvette C, Moënne-Loccoz Y. 2008.
The Rhizosphere: a playground and battlefield for soilborn pathogens and beneficial microorganism. Plant Soil. 321(1-2):341-361

Seghers D, Wittebolle L, Top EM, Verstmete W, Siciliano SD. 2004. Impact of agricultural practices on the Zea mays L. endophytic community. Appl Environ Microbiol. 70(3):1475-1482. doi: 10.1128/ AEM.70.3.1475-1482.2004

Sturz AV. 1995. The role of endophytic bacteria during seed piece decay and potato tuberization. Plant Soil. 175(2):257-263. doi: 10.1007/BF00011362

SturzAV, Christie BR, Matheson BG, Nowak J. 1997. Biodiversity of endophytic bacteria which colonize red clover nodules, roots, stems and foliage and their influence on host growth. Biol Fertil Soil. 25(1):13-19. doi: $10.1007 / \mathrm{s} 003740050273$

Sundaramoorthy S, Raguchander T, Ragupathi N, Samiyappan R. 2012. Combinatorial effect of endophytic and plant growth rhizobacteria against wilt disease of Capsicum annum L. caused by Fusarium solani. Biol Control. 60(1):59-67. doi:10.1016/j.biocontrol.2011.10.002.

West ER, Cother EJ, Steel CC, Ash GJ. 2010. The characterization and diversity of bacterial endophytes of grapevine. Can J Microbiol. 56(3):209-216. doi: 10.1139/ W10-004.

Yang CJ, Zhang XG, Shi GY, Zhao HY, Chen L, Tao K, Hou TP. 2011. Isolation and identification of endophytic bacterium W4 against tomato Botrytis cinerea and antagonistic activity stability. Afr J Microbiol Res. 5(2):131-136. 